\title{
EXPLORING NETWORKED IDENTITIES OF INDONESIAN HIJABERS
}

\author{
Alila Pramiyanti ${ }^{1}$ \\ Communication Department, Faculty of Communication and Business, Telkom University \\ Email: alilapramiyanti@telkomuniversity.ac.id
}

Naskah diterima tanggal 1 November 2018, direvisi tanggal 19 November 2018, disetujui tanggal 30 Januari 2019

\begin{abstract}
Abstrak. Penelitian ini membahas identitas jaringan jilbab Indonesia (istilah untuk wanita yang mengenakan jilbab yang sadar mode). Penelitian ini melakukan wawancara mendalam dan observasi partisipan terhadap dua puluh enam jilbab yang secara aktif mengambil bagian sebagai komite di komunitas jilbab. Istilah identitas jaringan telah dikembangkan untuk menyesuaikan bagaimana komunitas mewakili identitas di era internet. Sebagian besar komunitas mempertimbangkan pentingnya interaksi dan komunikasi yang dinamis dalam pembangunan identitas berjejaring. Mereka kebanyakan menggunakan Instagram untuk saluran komunikasi eksternal bersama dengan WhatsApp dan Line untuk saluran komunikasi internal. Para pembajak ini secara sadar percaya pada identitas mereka harus mewakili gambar Muslimah yang saleh (sebuah istilah untuk wanita Muslim). Selain itu, mereka juga mewakili dan mengkomunikasikan identitas jaringan mereka sebagai perempuan Muslim modern dan aktif yang menghasilkan tokohtokoh baru perempuan Muslim Indonesia.
\end{abstract}

Katakunci: Komunitas, Hijabers, Identity, Instagram, Indonesia, Jaringan.

Abstract. This paper examines the networked identities of the Indonesian hijabers (a term for hijabwearing woman who is fashion conscious). This study was undertaking in-depth interviews and participant-observations towards twenty-six hijabers who are actively taken part as a committee in the hijab communities. The term networked identity has been developed to adjust how community represents identity in the internet era. Most of the communities consider the importance of dynamic interactions and communication in the construction of networked identities. They mostly use Instagram for external communication channel along with WhatsApp and Line for internal communication channel. These hijabers consciously believe on their identities should be representing the images of pious Muslimah (a term for Muslim woman). Additionally, they also represent and communicate their networked identities as active and modern Muslim women that generate new figures of Indonesian young Muslim women.

Keywords: Community, Hijabers, Identity, Instagram, Indonesia, Networked. 


\section{INTRODUCTION}

Many scholars have different concepts of community. Feenberg \& Bakardjieva (2004) explained five characteristics of community: “(1) identification with symbols and ritual practices; (2) acceptance of common rules; (3) mutual aid; (4) mutual respect; and (5) authentic communication" (p. 5). Meanwhile, Delanty (2003) also explained the communicative process is the critical part to form a community. Based on Feenberg \& Bakardjieva (2004) and Delanty (2003)'s community concepts, this paper adopted the concept of the community as a communicative process. This paper focuses on communication as the critical attribute of community in regard to understand how the role of the communicative process in the construction of networked identity within six Indonesian hijab communities including: Hijabers Community (HC), Hijaber Gresik (HG), Hijaber United (HU), Yayasan Hijab Indonesia/Indonesia Hijab Foundation (YHI), Hijabie Community (HY), and Syar'i Lifestyle (SLS).

These hijab communities only have two required conditions for their member which is Muslim and woman. As Muslim woman-only communities, these hijab communities should be following several Islamic guidance, for example wearing modest clothes that cover aurat (parts of the body that should be covered). As such, these Indonesian hijab communities can be identified not only by their hijab but also by their Islamic practices that reflected in their community identity.

The sense of community identity has an essential role in supporting the formation and existence of community (Kendall, 2011). Similarly, Erikson (1959) said, "developing identity and finding out 'who you are and whom you want to be' is one of the key developmental tasks in modern societies" (in Schmidt, 2013). It means the construction of community identity is a significant part of the community's sustainability.

Meanwhile in the internet era, "identity is always networked since it can only be developed through interaction and communication in networks of social relationships where both personal and social cues are given (off) and connected to more or less stable conceptions of oneself" (Schmidt, 2013, p. 372). The term 'networked identity' provides the possibility to capture the complex relations between online and offline life (Ryberg \& Larsen, 2008). Furthermore, Schmidt (2013) argued: "Identity relies on both personal and social cues, and as networked identity - which is formed and performed in different mediated communication spaces - it can display various degrees of temporal stability, consistency, and recognizability" (p. 369). Schmidt's (2007) explained three frameworks of networked identity which consist of: 
1. Code is related to technological affordances of the platform and the constellations of hardware and software for online communication.

2. Rules are a complex set of social and cultural rules, values, norms consisting expectations about appropriate or inappropriate behaviour.

3. Relations encompass technological relations and social connections.

These three factors -code, rules, relations- influenced each other and determined the representation of networked identities (Schmidt, 2007). Code guides specific kinds of rules and assists in the formation of relations. Rules guide the use (code) of platform and influence the form of relations. Relations stabilise the rulesets and give feedback for continuous development of networked identity. Drawing on Schmidt's (2007) framework, this paper explores how the code, rules, and relations employed by the Indonesian hijab communities to provide knowledge on how these hijabers' perform their networked identities.

\section{RESEARCH METHOD}

This paper is part of broader research on Indonesian hijabers' self-presentation on Instagram. This study using the ethnographic method to examine the unique experiences of twenty-six young Muslim women who are active in the Indonesian hijab communities. Data for this study was collected through 45-60 minutes interviews from Sept until Dec 2016. Snowball sampling (Cresswell, 2007) was used in this study. These young (20-34 years old), middle-class, well-educated are interviewed in Indonesia's big cities; Jakarta, Bandung, Yogyakarta, Gresik. Interview transcripts were categorised by its themes for looking common concepts using thematic coding to find these hijabers' thematic concepts of code, rules, and relations as the frame of their networked identities.

\section{RESULT AND DISCUSSION}

As mentioned above, six hijab communities participated in this study including Hijabers Community (HC), Hijaber Gresik (HG), Hijaber United (HU), Yayasan Hijab Indonesia/Indonesia Hijab Foundation (YHI), Hijabie Community (HY), Syar'i Lifestyle (SLS).

Hijabers Community (HC), is the first and the most prominent hijab community in Indonesia. Some of the founders are famous young Muslim designers like Dian Pelangi, Ria Miranda, Jenahara, Siti Juwariyah, Fitri Aulia, Ghaida Tsurayya, Lulu el Hasbu, Rimma Bawazier. Since the end of 2017, this community has been actively communicating their tagline "to empower and inspire each other" through various events related to hijab and Muslim woman. 
Besides a headquarter in Jakarta, $\mathrm{HC}$ has thousands of members and ten official branches in several big cities in Indonesia such as Bandung, Yogyakarta, Banten, Bogor, Bekasi, Malang, Padang, Medan, Lampung, Pontianak.

This community has initiated the word of "hijabers" that derived from the word of hijab with the suffix -er plus 's' as plural meaning. The term of hijab that initially from Arabic, has replaced the word of "jilbab" and "kerudung" that commonly used in Indonesia before the 2000s to mention veil. HC chose to use the term "hijab-ers" than "jilbab-ers" in order to present the senses of internationally as well as Islamist. Then the term "hijabers" had associated with young Muslim women who wear a particular style of hijab, usually stylish colourful and fashionable.

Hijaber Gresik (HG) was founded in 2012 in Gresik, a satellite city nearby Surabaya, the capital city of East Java Province. This community was founded because at that time the main activities of the hijabers were located in Jakarta and Bandung area which is quite far from Gresik residencies. Unfortunately, there was no similar community in Surabaya; then they decided to establish HG. Now, this community is the most active hijab community in Eastern Indonesia. HG also had successfully become a partner of Dinas Pawisata dan Budaya Kapubaten Gresik (Gresik Tourism and Culture Office).

Another hijab community that involved in this study is Hijaber United (HU). It was founded in 2014 by www.diaryhijaber.com. This portal is also official HU's media partner. HU has more than 326 members with 16 branches in Jakarta, Bandung, Yogyakarta, Bogor, Bekasi, Tangerang, Solo, Semarang, Malang, Kendal, Pekalongan, Surabaya, Makassar, Palembang, Medan, Lampung. Since 2016, this community launch Hari Hijabers Nasional (Hijabers National Day) supported by Indonesian Minister of Social Affairs, Khofifah Indar Parawansa.

Yayasan hijab Indonesia/Indonesian Hijab Foundation (YHI) was founded in August 2014 by a finalist of Jakarta's beauty pageant, Ayu Wulandari. YHI is designed to serve as a community for Muslim women who are caring about education, environment, art and culture. In the first anniversary, YHI held an event called Charity in Harmony and established Hijab School Indonesia.

Besides in Jakarta and Bandung, the phenomenon of hijabers is also happening in Yogyakarta. For example, Hijabie Community (HY) was established in Yogyakarta on 22 November 2014, founded by two cousins, Atika Maulida and Diana Fatimah Azzahra. They chose the term 'hijabie' as differentiation from the usual term of 'hijabers'. HY aims to be a learning place for Muslim women. At the beginning of the establishment, HY members only amounted to 80 people, but in 2017, its members are already nearly 300 people who have registered with around 150 number of active members. HY has 8 active divisions currently in the 
field of makeup, modelling, public speaking, journalism, culinary, religion, photography, and entrepreneur. Now HY exists in 3 cities namely Yogyakarta, Solo, and Magelang.

Syar'i Lifestyle (SLS) was founded by two fashion designer Fitri Aulia, the owner of brand Kivitz, and Dian Marina, the owner of brand Missmarina, in Jakarta in 2015. Fitri Aulia was also one of HC's founder. The vision and mission of SLS are to create rabbani (divine) generation by studying and applying Islamic sharia values to all aspects in Muslim women lifestyle, such as modest fashion, halal food, halal tourism, syar'i lifestyle and good morals.

\section{Instagram as the Primary Communication Channel}

Although in this digital age, the assumptions of the Internet affect to community have been developed into three ways in which "the internet decreases community, the internet transforms community, the internet supplements community" (Wellman et al., 2006, p. n.d), but related with this study, the internet seems transform and supplement the hijab communities especially in term of their communication process.

Communication develops when the process of ideas sharing could be interpreted and created social context (boyd \& Heer, 2006). This study found these communities mostly used Instagram for communication tools with their members, followers and public audiences.

As the most prominent community, $\mathrm{HC}$ has 98 thousand followers on Instagram. HG now has around 11 thousand followers. Meanwhile until September 2017, HU has 6,832 followers, YHI has 4k followers, and HY has 6,246 followers on Instagram. Even though it was just established a year ago, SLS has more than 9k followers on Instagram.

The hijabers have shifted the most used platform from Twitter to Instagram for communication medium within communities. They described four reasons of this shifting as (1) most of their followers not often using it, (2) Instagram is 'trendy' and kekinian (modern/contemporary), (3) the simplicity of Instagram, and (4) its capacity to create visual storytelling.

First, they no longer using Twitter because most of their followers are not often using Twitter anymore. Atika, chairwoman of Hijabie Community Yogyakarta, said "(we are) not using Twitter anymore. It is 'quiet'...(and) because the majority of our members are not using Twitter". The word 'quiet' means there is not much excitement on Twitter. This platform has become 'a boring platform' for Indonesian youth people because its contents are more about politics and black campaigns, news, and company publications.

Another reason why they are not often using Twitter because of the limitation of 140 characters. This limited space is not enough to express themselves more deeply. Twitter has few 
characters; it is only 140 characters. It is different from Instagram that has hundreds of characters. The space for self-expression in Twitter is limited.

Secondly, Instagram is a 'trendy' platform, most of the Indonesian young people using it, no exception the hijabers. Communities think Instagram is a modern platform. It is the most developed, interesting, and up-to-date platform. Shafira, public relations of Hijabers Community Bandung, stated "Instagram is the most used platform because it is the most updated and it (community's Instagram account) is frequently updated. So today people are more often using Instagram".

Kekinian or contemporary is a favourite word used by Indonesian youth to express something very up-to-date. Hijabers Community Bandung's vice chairwoman, Ifa, also explained that her community using Instagram because Instagram is modern "why do we use Instagram? Because we (community) want to follow modernity/contemporary". Meanwhile, the community also needs to show its existence by adopting Instagram's platform, like Wanda (administrator social media accounts of Hijabers Community Jakarta) explained: "recently (the community is) using Instagram because of its contemporary, so we need to be presented there".

Third, the simplicity of Instagram and its broader coverage had made Instagram as the most effective and practical platform because it easily relates to other platforms. Sarah; chairwoman of Hijabers Community Bandung; prefers using Instagram for sharing community's events because Instagram has the complete feature including texts, photos and videos sharing. She said "We are no longer using Twitter. We can link to other platforms from Instagram. We are looking for practicality and multifunctionality".

Another participant who is a committee in Hijabers United Bandung, Maya, likes Instagram because of its fastness in sharing information, "I prefer Instagram because the information in Instagram has developed faster than another social media”. Moreover, according to Syifa; chairwoman of Hijabers Community Jakarta; her community is using Instagram due to the directness of communication.

Lastly, besides its simplicity, Instagram has also claimed by the participant as a platform which has the best capacity to generate visual storytelling. Ifa said, "HCB realise the big impact of Instagram is its visual capacity that provides colourful pictures. It gives greater impacts on HCB's events and photographs". As a phrase "picture can tell a thousand words", participants believe the pictures/photos already said many words. Therefore, they can express their feelings and thoughts without necessary to write a wordy caption.

By means of Instagram, these communities had exposed their identity through photographs, captions, number of followers, number of loves. New forms of identity are shaping 
communication, and new forms of communication are shaping identity (Dunn, 2013). In other words, Instagram is an important communication platform to connect the members, to share vision and mission, to build communication culture, to increase the sense of belonging, and to maintain relationships that will be helped the formation of networked identities

Besides Instagram, these communities also use WhatsApp and Line not only to coordinate but also to establish relationships and to advance solidarity with their committees and members.

\section{The Networked Identity of the Hijab Communities}

The community has transformed into networks to accommodate the development of communication technology. These networks are then creating networked publics which explained by boyd (2011) as "public that are restructured by networked technologies that simultaneously (1) the space constructed through networked technologies and (2) the imagined collective that emerges as a result of the intersection of people, technology, and practice" (p.39). Networked publics will be formed a specific networked identity. By applying Schmidt's (2007, 2013) framing of networked identity, following paragraphs explore the three factors of networked identity, which is code, rules, and relations.

The code is related to technological affordances of the platform and the constellations of hardware and software for online communication. "Identity is increasingly constructed and performed via networked media that include their affordances and limitations" (Schmidt, 2013, p. 365). This section will discuss how the visual affordances of Instagram and the feature of Instagram usually used by communities.

The affordance concept explains why similar technology could generate different meaning and interpretation. However in communication studies, affordance refer to putting the control of technologies to its users rather than to the technologies itself or their creators, as noted by Nagy and Neff (2015), "most frequently refer to what users and their sociality get from a technology" (p.2). In this paper, the affordances as part of the code in the networked identity formation will explain why the hijab communities use Instagram, how they use it, and for what purposes.

These hijab communities are also explaining the functionalities of Instagram as a platform to share information, to promote community's events, to publicise sponsorship and endorsement, to broadcast community's programs as well as a medium for members' registration.

The social media's administrator of Hijabers Community (HC) will adjust the messages according to the platforms, e.g. shrink the information into 140 characters for Twitter while more comprehensive news available in the blog. Facebook provides the ability to post photos and videos, and Instagram is more real-time with a lesser caption. The photos or pictures could 
explain everything. HC is used Instagram to blast community's activities. Syifa, the chairwoman, said, "Our Instagram is about our activities, networking, cooperation, sponsorship, endorsement". Moreover, through Instagram, HC always try to collect charity every month then we will donate it directly to the needed". The most active HC's followers are they are who under the 20s, or university students, or bloggers. They are active in giving comments, asking their friends to follow $\mathrm{HC}$, mentioning $\mathrm{HC}$ in their posts, and helping answering FAQ about HC. Active followers would help admin to answer FAQ about HC's events/programs.

Instagram as a platform to share information is stated by all communities' committee. For instance, Sarah - the chairwoman of Hijabers Community Bandung (HCB), said: "the main purpose of using social media is for sharing information and quotes". Social media has a more significant impact on HCB's events promotion than media partners. HCB using Instagram because it is a modern platform. HCB realise Instagram is a platform with a visual ability that could bring great exposure to HCB's events. Instagram is very different with Twitter which only focuses with words. Even though she can post Twitpic but most people will not open it. It is different from Instagram when followers will automatically see both the picture and the caption.

HCB's accounts have many followers because they always maintain its contents. There is no intention to build a forged image in social media, "we posted what we were doing. However, we also realise that we need our active followers to increase our positive image" said Sarah. HCB always update their Instagram account every 2-3 times a week depending on their events or sponsorship obligation and posting hadiths every week. In term of event organising, there are some guidelines such as registration via Instagram or Line before the event to know the target audience, provide a person in charge to broadcast live tweet and Instagram, tagged committee who in charge in the event as a form of appreciation.

According to Udhe, chairwoman of Hijabers Gresik (HG), her community mostly use Instagram and Facebook to share info about community's events and activities, Islamic knowledge, fiqih, and hadiths, as well as an invitation and reminder for attending their events. While Facebook mostly utilises to copy-paste links from Islamic website, Instagram is used to distribute the community's original ideas.

Meanwhile, Syari Lifestyle's (SLS) chairwoman, Fitri said "Instagram is using for sharing short messages, daily reminder, quotes from the Quran. Instagram content should be fun. Our target is dynamic and cheerful women that is why information posted on Instagram should be using a good photograph, graphics, and images with a bright colour like red, fusion, yellow like our colour trademark". Her community realises that every platform has a different function. They have a blog which containing detail discussion about one topic then they summarised it 
into some points and shared it through Instagram. So, Instagram is used to post essential points and less wordy with the link to their blog such as a daily magazine, daily worship like Dhuha prayer and read Al-Kahfi on Friday.

For Hijabers United (HU), Instagram is mostly used to publicise and invite our members to the community's events. "We have already held charity programs called nasi bahagia "happy rice”, a holiday to Tidung island, and Hari Hijabers Nasional (National Hijabers Day)", said Dewi, a committee of HU.

Similar with another community, Ayu as chairwoman of Yayasan Hijab Indonesia (YHI/Indonesia Hijab Foundation) also using Instagram for sharing information, updating and documenting her community's events. Even though her community did not have any new events, she always tries to post or share any information to keep her account updated.

Rules are a complex set of social and cultural rules, values, norms consisting expectations about appropriate or inappropriate behaviour. The hijab communities have some community guidelines of a platform and boundaries about what they may and may not to present in social media. They are setting the boundaries by referring to the Islamic way of life.

Being thoughtful before sharing is fundamental guidance for them. For example, as a chairwoman of HC and a public figure, Syifa consider if she should be thoughtful and careful with her posts because she is not only presenting herself but also many organisations that she is involved in and her family's good reputation. HC will not post any content that may offend or insult certain groups or hurt somebody's feelings. HC's postings should be understandable by their varied followers and not becoming provocative to avoid controversy. HC always tries to avoid posting that could divide Muslim into different groups. HC prefers to post educative contents.

The same consideration is also realised by Ghaida, as a public figure an, fashion designer and advisory board member of Hijabers Community Bandung, she has a big responsibility to maintain her family pesantren (Islamic school) reputation. She is applying Islamic principal about amanah (fulfilling or upholding trusts) in her social media activities. Ghaida believes everything we did in our life should be accountable to Allah, including her posts in social media. She said, "the more followers we have, the bigger the amanah we take because they (followers) will be following our behaviour and our behaviour should be accountable to Allah". Therefore, Sarah as the chairwoman of Hijabers Community Bandung (HCB), she also always tried to be amanah (trusted).

Islam has regulated the relationship between man and woman. Echa, a committee of Hijabers Community Yogyakarta, knows that rule, so she tries to avoid taken photo with a man 
too close because photographs in social media posting can mislead the followers. She said, "social media is easily misinterpreting. For example, if we were photographed with men, it could reflect the closeness (between unmarried man and woman) that should be avoided by us (Muslims)".

Udhe also stated that her community, HG, has a rule not to post something that exposes "aurat" (a particular part of the body that we need to cover from others to see). This community is also not approving a friend request from man.

Meanwhile, as a new community, a chairwoman of Hijabie Yogyakarta (HY), Atika, have to handle and take full in charge and responsibility in the community's social media account. She prefers to use WhatsApp and Line as an internal medium of communication. She is using these internal communications for reporting and supporting her members.

Meanwhile HU has central rules that organised by the central committee in Jakarta. Maya, a committee from HU Bandung said "Central committee has a crucial part to decide what our community should or should not post. Our post cannot be related to SARA (Suku, Agama, Ras, Antargolongan / Ethnic, Religion, Race, Among Groups)”. Besides Instagram, HU is also using their website www.daily hijabers.co.id as their main portal to publicise their programs.

Fitri, fashion designer, former founder of Hijabers Community and now chairwoman of SLS community, refers Islamic teaching regarding Islamic sharia law as the core rule of her community. Her followers require her to be more selective in deciding what she will be posted on social media. For example, she cannot post eating Japanese food without a halal label on it or drinking without taking a seat. Additionally, Fitri is also obeying Islamic teaching about prohibition to show nudity. She does not want to post inappropriate and contrary photos, for example, she must cover nude statues with fabrics before she took the photo in front of it.

SLS has a very well-arranged flow of posting. There is a content team who responsible for preparing the scripts and creating the graphics of the blog's content within around 1-1.5 months before its due date. The coordinator of the content team then will consult to community's sharia board. The board will check the content; they will check the Quran verses and hadiths to avoid share dhoif (weak) hadiths. After that, the content will be sent to the secretary and to the creative team to insert the photographs or pictures. Then the content will be sent back to the secretary and will be uploaded by her.

Ayu, a chairwoman of YHI, admitted that the rules are tried to post something neutral, avoid involving in controversial issues or share conflict news. She strictly stated that she will not post any products or sponsors that did not support YHI's events or could harm YHI's images. 
One more boundary that expressed by a participant is regarding protecting privacy while online. Feeling secure when existing in social media is essential. Thus some of them lock their accounts. For example, one of the participant, Adina said "I am being been careful in social media. I locked my Twitter and Instagram. So, I only accept a friend request from an old male friend that I know, but if he is a new friend, I usually take a long consideration because there are many photos of my face in Instagram".

Relations encompass technological relations and social connections. Relations can give some cues about the community's interests, how the communities represent and express their identity and how community form particular audiences.

HC has six committees who are in charge of public relations officer (PRO) who responsible for maintaining good relations with internal and external publics. There is an image $P R O$ who responsible for advising any invitations to $\mathrm{HC}$, an email PRO who responsible to reply and answer all email, and the last four PRO has a duty as social media PRO who responsible for selecting and approving the content of the blog, Facebook, Twitter, and Instagram. Partnership process in $\mathrm{HC}$ is starting by submitting a proposal via email to Public Relations division, then from PRO the proposal is discussed through committee's WhatsApp group then continued in a face-to-face meeting.

$\mathrm{HC}$ is also posting greetings or celebrations of essential dates in Islamic Calendar and Indonesian national days to show community's existence. HC also established collaboration with a charity foundation called ACT (Aksi Cepat Tanggap or Fast Response Action). For instance, they promote the importance of giving and caring each in others while celebrating "Sacrifice Feast" or Eid Al- Adha. HC helped ACT to educate Muslim people how to distribute the meats to the right people, through games.

HC creates Instagram's messages with plain and straightforward hijabers' languages and attractive, colourful graphics to easily get attention from followers. HC always asks their community's partner to adjust their content with the language of hijabers. By using hijabers' languages, they hope the messages will be more manageable to read, understandable and at the same time will be not patronising.

$\mathrm{HC}$ also had tried to make user-generated content such as using \#ibadahjangankendor (hashtag do not "slackly" the worship) as a Ramadhan's challenge. Using this hashtag, HC asked followers to be more active and do a simple sincere thing as many as possible in the holy month of Ramadhan. HC reposted the most interesting content using \#ibadahjangankendor as a reward. Besides, create user-generated content, $\mathrm{HC}$ also re-post reminder from muslimah.or.id or 
Muslim.or.id if the content suitable with their audiences. HC tries to post that suitable and understandable by the hijabers and hoping their followers will

As the branch of $\mathrm{HC}, \mathrm{HC}$ Bandung (HCB) realised the significant role of social media in building relations in order to perform community identity. Social media has a crucial role in HCB because almost all of activities, from member registration to media partner, are using social media. "Social media is like the heart of the community", said Ghaida, advisory board member of HCB. Information about pengajian should be posted more intensive in Day minus 2 of the event and sponsorships should be posted as the agreement. HCB mostly posts 2-3 updates per week about quotes and hadiths (every Friday), live update in 'pengajian' (Islamic lecturing), share the photos after pengajian, charity, sponsor and media partners flyers. HCB also has two PRO, internal and external. For the partnership process, people should contact HCB by email and then face-to-face meeting. For HCB, Instagram is a channel to build a positive image by sharing quotes, activities, events, sponsorships, charity, gathering. They believe by sharing it on Instagram; young Muslim women will consider $\mathrm{HCB}$ as fun, exciting, helpful community and then become interested in joining the community, tag their friends to follow community's Instagram account and come to community's events.

Some of these communities have one or more persons accountable as social media administrators. HC has three or four administrators in every branch, HG has three social media administrators for Facebook, Twitter, and Instagram, HU has one admin in HU Jakarta, SLS using the position of secretariat as an administrator. However, a centralised style of organising found in HY and HYI. The chairwoman handles all the structure functions in the community. Both HY and YHI's chairwomen admitted they were quite demanding and perfectionist persons. They prefer to handle all functions rather than manage an ordinary event that do not reflect their community's images and identities. Meanwhile, HU has a centralised division of PR, marketing, design and sponsorship in Jakarta that arrange community's events.

\section{CONCLUSION}

To sum up, in term of code, all communities use Instagram as their primary communication channel. The main reason for using Instagram is because of its popularity and contemporary aspect and visual capability in displaying impressive photographs. I found that HC and SLS as the most ideal communities in adopting Instagram as their communication channel. Meanwhile, all hijab communities apply the same rules that the content of Instagram, WhatsApp, and Line should be following the corridor of Islamic values and norms. Then in relations, the 
communities manage to build networking with local and national institutions in order to increase their image and prestige.

Taking the expression from Rainie \& Wellman (2012) "the World According to the Connected Me", which mean we live in the era where people prompt to communicate their stories and ideas and then invite conversation and feedback, I found these hijab communities have been promoting their programs, sharing Islamic knowledge, and encouraging young Muslim women to be active and creative. They shape and perform their unique networked identity as pious, active, and modern young Muslim women.

Instagram is a modern manifestation of networked identity presentation. In involving social media into community existences, these hijabers have changed the ways they communicate and interact with each other because Instagram has been extending and enhancing their community identity. It has exemplified communities' impression management which shared clues about community identities. These hijab communities carefully draw attention to their postings. They regulate and select which message is appropriate and not appropriate to share. Thus, their effort in presenting networked identity is, consciously or not, engaged with their impression management strategy to build good images of the communities.

\section{REFERENCES}

\section{Journal:}

Boyd, D. 2011. Social Network Sites as Networked Publics: Affordances, Dynamics, and Implications. In Z. Papacharissi (Ed.), A networked self : identity, community and culture on social network sites. New York: Routledge. https://doi.org/10.4324/9780203876527

Dunn, R. A. 2013. Identity theories and technology. In Handbook of research on technoself: Identity in a technological society (Volumes 1-2) (pp. 26-44). https://doi.org/10.4018/9781-4666-2211-1.ch002

Nagy, P., \& Neff, G. 2015. Imagined Affordance: Reconstructing a Keyword for Communication Theory. Social Media + Society, 1(2), 2056305115603385. https://doi.org/10.1177/2056305115603385

Ryberg, T., \& Larsen, M. C. 2008. Networked identities: Understanding relationships between strong and weak ties in networked environments. Journal of Computer Assisted Learning, 24(2), 103-115. https://doi.org/10.1111/j.1365-2729.2007.00272.x

Schmidt, J. 2007. Blogging practices: An analytical framework. Journal of Computer-Mediated Communication, 12(4), 1409-1427. https://doi.org/10.1111/j.1083-6101.2007.00379.x

Schmidt, J. H. 2013. Practices of Networked Identity. In J. Hartley, J. Burgess, \& A. Bruns (Eds.), A Companion to New Media Dynamics (pp. 365-374). Blackwell Publishing Ltd. https://doi.org/10.1002/9781118321607.ch24

Wellman, B., Quan-Haase, A., Boase, J., Chen, W., Hampton, K., Díaz, I., \& Miyata, K. 2006. The Social Affordances of the Internet for Networked Individualism. Journal of Computer-Mediated Communication, 8(3), 0-0. https://doi.org/10.1111/j.10836101.2003.tb00216.x 


\section{Book:}

Cresswell. J. W. 2007. Qualitative inquiry \& research design: Choosing among five approaches. Thousand Oaks: Sage Publications.

Delanty, G. 2003. COMMUNITY. New York: Routledge.

Feenberg, A., \& Bakardjieva, M. (2004). Consumers or Citizens? The Online Community Debate. In A. Feenberg \& D. Barney (Eds.), Community in the Digital Age. Lanham: Rowman \& Littlefield.

Kendall, L. 2011. Community and the Internet. In M. Consalvo \& C. Ess (Eds.), Handbook of Internet Studies. (pp. 315-331). Chichester, West Sussex: Willey-Blackwell.

\section{Proceeding:}

Boyd, D, \& Heer, J. 2006. Profiles as conversation: Networked identity performance on friendster. In Proceedings of the Annual Hawaii International Conference on System Sciences (Vol. 3, pp. 1-10). https://doi.org/10.1109/HICSS.2006.394

\section{Website:}

Rainie, L., \& Wellman, B. 2012. The New Social Operating System of Networked Individualism. In Networked: The New Social Operating System. Retrieved from http://www.jstor.org/stable/j.ctt5vjq62.5 